\title{
Microbiological profile of potato samples collected from Bangladesh Agricultural Research Institute (BARI) and notification of anti-bacterial traits
}

\author{
Mushfia Malek, Mrityunioy Achariee and Tasmina Rahman* \\ Department of Microbiology, Stamford University Bangladesh, 51 Siddeswari Road, Dhaka 1217, \\ Bangladesh
}

Received 17 May 2013/Accepted 5 July 2013

\begin{abstract}
Present study assessed the microbiological quality of different categories of consumable potatoes collected from Bangladesh Agricultural Research Institute (BARI), the largest multi-crop research institute of the country conducting research on a large number of crops. Five samples each from 15 categories of potato samples (Lara, Quincy, Cardinal, Esprit, Meridian, Lady Rossetta, Astrix, Soikat, Red potato, White potato, Russet potato, Yellow flesh potato, Sweet potato, Purple potato and Petiets potato) were subjected to microbiological analysis through conventional culture followed by the biochemical identification tests of the pathogens. A huge array of bacterial and fungal contamination was noticed within a range of $\left(\sim 10^{8} \mathrm{cfu} / \mathrm{g}\right)$ in almost all samples studied. Among the bacterial pathogens, Escherichia coli and Staphylococcus spp. were found to be predominant. Study of antibiogram revealed that most of the isolates were resistant against the commonly used one or multiple antibiotics. Finally, all the samples were also examined for presence of any anti-microbial activity against different pathogenic bacterial species. Astrix potato samples exhibited antimicrobial activity against Shigella spp and the Russet potato samples exhibited the anti-bacterial activity against Staphylococcus spp.
\end{abstract}

Key words: Potato; Microbiological quality; Drug-resistance; Antimicrobial activity; Consumer safety

Potato is one of the major and popular food items around the world (Solanum tuberosum) because of its high nutrient content as well as for its easy cultivation procedures (1-3). Production of potatoes at larger scale is necessary to convene the nutritional demands of huge population in developing countries like Bangladesh (2, 4). More than 3000 species of potato have been found in a large plant family of Solanaceae. On the basis of their production rate (325 thousand tons in 2007), potato is the third most important food crop after wheat and rice (5).

Because of the nutritional benefit, vegetables are being increasingly consumed and included in our daily meals almost every day (6-9). Potatoes, one of the most productive crops/ vegetables, have long been playing a significant role in ensuring food security globally. Bangladesh, an agro-based country, is well known to be the major potato producer in the South-East Asia. However, like other raw fresh vegetables, potatoes may also come in contact with an array of microorganisms including Aeromonas spp., Bacillus cereus, Campylobacter jejuni, Clostridium botulinum, E. coli O157:H7, Listeria monocytogenes, Salmonella spp.,

"Corresponding Author: Mailing address. Tasmina Rahman, Department of Microbiology, Stamford University Bangladesh, 51 Siddeswari Road, Dhaka 1217, Bangladesh, Bangladesh; E-mail: tasmina_mb@yahoo.com.
Shigella spp., Staphylococcus spp. and Vibrio cholerae, resulting in various diseases (10-16). Therefore, survival and growth of pathogens in raw fresh vegetables are of paramount importance with respect to spread and transmission of diseases in humans and animals.

Potatoes are processed into many products including frozen, dried, ready-to-eat and minimally processed products. The potential risk of consumption of contaminated potato is lower than from other fresh vegetables because this commodity is cooked before eating. However, contaminated potato represents a potential risk of cross-contamination of other fresh vegetables in the processing plant and at home. Additionally, increased consumer demand for new and existing potato products highlights the importance of ensuring their microbiological safety $(2,4)$. Moreover, the concern for pathogens in vegetables including potatoes has risen due to the emerging outbreaks of food borne illness causative of the consumption of the minimally processed vegetables (17). Another health related issue lies over the antibiotic abuse which has been reported to extend the risk of acquiring resistance in the pathogens which badly affects the medication (18-22). The probability of dissemination of drug resistant pathogens in vegetables through contaminated water and/or other means is of great public health importance. 
Along these lines, present research attempted to detect and quantify total viable bacteria, total and fecal coliforms, and specific pathogens in the collected potato samples; to demonstrate the drug-resistance traits of the pathogenic isolates; and finally to investigate the antimicrobial activity (if any) of the potato sample of current interest.

\section{MATERIALS AND METHODS}

Study area, sampling and sample processing. Samples of 15 categories of healthy potato including Lara, Quincy, Cardinal, Esprit, Meridian, Lady Rossetta, Astrix, Soikat, Red potato, White potato, Russet potato, Yellow flesh potato, Sweet potato, Purple potato and Petiets potato were collected from Bangladesh Agricultural Research Institute (BARI) following standard protocol (23). Samples were quickly transported to the laboratory, and prior to microbiological assay, $10 \mathrm{~g}$ of each samples with $90 \mathrm{ml}$ buffer peptone water $(\mathrm{pH} 7.2 \pm 0.2)$ and the homogenized clear liquid was transferred into sterile airtight bottles (16). The homogenized samples were diluted up to $10^{-6}$ by following the standard methods of 10 fold dilution (24).

Enumeration of total viable bacteria and fungi. An aliquot of $0.1 \mathrm{ml}$ from the dilution $10^{-3}$ and $10^{-6}$ of each sample was spread onto nutrient agar (NA) plate (Hi-Media Laboratories Pvt. Ltd., India) for enumerating total viable bacteria (TVB) and on Sabouraud Dextrose agar (SDA) plate (Hi-Media Laboratories Pvt. Ltd., India) for the estimation of fungal load, by means of spread plate technique (24). Plates were incubated at $37{ }^{\circ} \mathrm{C}$ and $25^{\circ} \mathrm{C}$ for 24 48 hours for bacterial and fungal enumerations, respectively.

Estimation of total fecal coliform, Escherichia coli and Klebsiella spp. From the dilutions $10^{-3}$ and $10^{-6}, 0.1 \mathrm{ml}$ of each sample was spread onto the membrane fecal coliform (MFC) agar and MacConkey agar (Hi-Media Laboratories Pvt. Ltd., India) for the enumeration of total fecal coliform (TFC), and coliforms (i.e., Escherichia coli and Klebsiella spp.), followed by incubation at $44.5^{\circ} \mathrm{C}$ and $37{ }^{\circ} \mathrm{C}$ for fecal coliform and coliforms, respectively for 24 hours.

Estimation of Salmonella spp., Shigella spp., and Vibrio spp.. Enrichment was performed for Salmonella, Shigella and for Vibrio spp. in order to avoid the false negative results $(16,25,26)$. After homogenization, $10 \mathrm{ml}$ of samples were transferred into $90 \mathrm{ml}$ of selenite cysteine broth (Oxoid Ltd., Basingstoke, Hampshire, England) and alkaline peptone water (APW) for the enrichment of Salmonella, Shigella, and Vibrio spp., respectively and incubated at $37{ }^{\circ} \mathrm{C}$ for 4-6 hours $(16,25,26)$. Samples were then diluted up to $10^{-6}$ and $0.1 \mathrm{ml}$ of samples from each of the $10^{-3}$ and $10^{-6}$ dilutions were spread onto SalmonellaShigella (SS) agar (Hi-Media Laboratories Pvt. Ltd., India) and thiosulfate citrate bile salt sucrose (TCBS) agar (Hi-Media Laboratories Pvt. Ltd., India) for the isolation of Salmonella spp. and Shigella spp., and Vibrio spp., respectively. Plates were incubated at $37{ }^{\circ} \mathrm{C}$ and the appearance of typical colonies (if any) was noticed within for 24-48 hours.

Isolation of Staphylococcus spp., Pseudomonas spp., and Bacillus spp. 0.1 $\mathrm{ml}$ from the dilution $10^{-3}$ and $10^{-6}$ was inoculated onto the mannitol salt agar (MSA) (Hi-Media Laboratories Pvt. Ltd., India), cetrimide agar plates (HiMedia Laboratories Pvt. Ltd., India) and phenol red egg yolk polymyxin (MYP) agar base media (Oxoid Ltd., Basingstoke, Hampshire, England) following the spread plate technique and incubated at $37^{\circ} \mathrm{C}$ for 24 hours for the isolation of Staphylococcus spp., Pseudomonas spp., and Bacillus spp., consecutively. Finally, the standard biochemical tests were performed to confirm the identification of all the pathogenic isolates found in all 15 types of categories of healthy potato samples by the previously described methods $(24,27,28)$.

Antibiotic susceptibility test. The pathogenic isolates were examined for antibiotic susceptibility traits by disk diffusion assay on Mueller-Hinton agar (Difco Laboratories, Detroit, MI, USA) against commonly used antibiotics following the standard protocol (22, 28-31). Antibiotic disk (Oxoid Ltd., Basingstoke, Hampshire, England) used in the study included trimethoprime/sulfamethoxazole $(25 \mu \mathrm{g} / \mathrm{disc})$, erythromycin $(15 \mu \mathrm{g} / \mathrm{disc})$, amoxicillin $(30 \mu \mathrm{g} / \mathrm{disc})$, ceftriaxone $(30 \mu \mathrm{g} / \mathrm{disc})$, ciprofloxacin $(5 \mu \mathrm{g} / \mathrm{disc})$, streptomycin $(10 \mu \mathrm{g} / \mathrm{disc})$, ampicillin $(10 \mu \mathrm{g} / \mathrm{disc})$, tetracycline $(30 \mu \mathrm{g} / \mathrm{disc})$, chloramphenicol $(30 \mu \mathrm{g} / \mathrm{disc})$, cefixime $(5 \mu \mathrm{g} / \mathrm{disc})$, polymyxin $\mathrm{B}$ (300 units/disc), kanamycin $(30 \mu \mathrm{g} / \mathrm{disc})$, vancomycin $(30 \mu \mathrm{g} / \mathrm{disc})$, gentamicin $(10$ $\mu \mathrm{g} /$ disc $)$, nalidixic acid $(30 \mu \mathrm{g} /$ disc $)$, azythromycin $(15 \mu \mathrm{g} / \mathrm{disc})$ and penicillin $\mathrm{G}(10 \mu \mathrm{g} / \mathrm{disc})$.

Determination of antibacterial activity of the potato samples. Agar well diffusion method was performed to determine the antibacterial activity of the potato samples $(32,33,34)$. Individual bacterial pathogens (Pseudomonas spp., Vibrio spp., Salmonella spp., Shigella spp., Klebsiella spp., Staphylococcus spp., E. coli) were spread properly over the MHA agar plates using sterile cotton swab and wells were made in the MHA by cork borer. Each of the blended potato samples was then introduced separately in the specified well along with a positive control (antibiotic disk) and a negative control (normal saline). Presence of clear zone (if any) indicated the presence of antibacterial activity (34).

Statistical Analysis. All the experiments were performed in triplicate. Statistical analyses were performed by determining the P-value through t-test. Errors were also calculated (35).

\section{RESULTS AND DISCUSSION}

A large number of populations in developing countries like Bangladesh are always affected by some enteric diseases those are mainly caused by contaminated food and water (36). Therefore, for the consumers health safety, it is necessary to conduct studies which are directly and indirectly associated with microbiology of food and water. Bacterial proliferation including drug resistant ones in food items is responsible for serious health risk (37). Thus the present study may increment the vegetables research regarding our food quality.

Prevalence of microorganisms. All the potato samples studied were found to be highly contaminated with bacteria and fungi (Table 1). Specific microbial existence was further confirmed with biochemical identification tests (Table 2).

The presence of $E$. coli was observed within the range of $10^{4}$ to $10^{7} \mathrm{cfu} / \mathrm{g}$ in all samples expect Red, Russet and Petites samples. Pseudomonas spp. $\left(10^{5}\right.$ to $\left.10^{7} \mathrm{cfu} / \mathrm{g}\right)$ was also detected in Lara, Cardinal, Esprit, Meridian, Lady Rossetta, Soikat samples. Salmonella spp. $\left(10^{6}\right.$ to $10^{7}$ $\mathrm{cfu} / \mathrm{g}$ ) was found in Lara, Quincy, Meridian and Petites samples, rest of the samples were free from the contamination with Salmonella spp. Cardinal, Esprit, Lady Rossetta, Red potato, White potato, Russet potato, Yellow flesh potato and Purple potato were found to be contaminated with Shigella spp. (10 $10^{5}$ to $\left.10^{7} \mathrm{cfu} / \mathrm{g}\right)$. Vibrio spp. was encountered $\left(\sim 10^{5} \mathrm{cfu} / \mathrm{g}\right)$ only in Quincy and Meridian. Among the 15 categories, only 2 categories of potato samples (Lara and Quincy) were contaminated with Bacillus spp. (10 5 to $\left.10^{6} \mathrm{cfu} / \mathrm{g}\right)$. All samples were found to be highly contaminated with Staphylococcus spp. $\left(10^{5}\right.$ to $\left.10^{8} \mathrm{cfu} / \mathrm{g}\right)$. Only Astrix and Purples samples were found to be contaminated with Klebsiella spp. up to $10^{7}$. Additionally, all the samples were found to be contaminated with fungal species within a range of $10^{5}$ to $10^{7} \mathrm{cfu} / \mathrm{g}$.

Cultivation of vegetables may largely account for such microbiological contamination. Manures used to promote the growth of vegetables may contain a large number of spoiling microorganisms $(16,38)$. Pathogens associated with untreated manure are assumed to enter into the food chain through crop. Thus, vegetables grown in such assistance of untreated fertilizers may play a significant role in showering pathogens to the consumers and therefore poses a great risk to public health (16). Moreover, the presence of microorganisms in potato samples studied might be largely due to the mishandling 
TABLE 1. Bacterial load (cfu/g) in the tested potato samples

\begin{tabular}{|c|c|c|c|c|c|c|c|c|c|c|}
\hline Sample & TVB & E. coli & $\begin{array}{c}\text { Klebsiella } \\
\text { spp. }\end{array}$ & $\begin{array}{l}{ }^{*} \text { Salmonella } \\
\text { spp. }\end{array}$ & $\begin{array}{l}\text { "Shigella } \\
\text { spp. }\end{array}$ & $\begin{array}{l}{ }^{*} \text { Vibrio } \\
\text { spp. }\end{array}$ & $\begin{array}{c}\text { Pseudomonas } \\
\text { spp. }\end{array}$ & $\begin{array}{l}\text { Staphylococcus } \\
\text { spp. } \\
\end{array}$ & $\begin{array}{l}\text { Bacillus } \\
\text { spp. }\end{array}$ & Fungi \\
\hline $\begin{array}{c}\text { Lara } \\
(\mathrm{n}=5)\end{array}$ & $7 \times 10^{8}$ & $5 \times 10^{4}$ & 0 & $2.4 \times 10^{7}$ & 0 & 0 & $1.2 \times 10^{5}$ & $1.5 \times 10^{7}$ & $5.7 \times 10^{5}$ & $1.98 \times 10^{6}$ \\
\hline $\begin{array}{l}\text { Quincy } \\
(n=5)\end{array}$ & $7.4 \times 10^{8}$ & $6 \times 10^{7}$ & 0 & $9.2 \times 10^{7}$ & 0 & $1.72 \times 10^{5}$ & 0 & $1.6 \times 10^{8}$ & $1.3 \times 10^{6}$ & $2.64 \times 10^{6}$ \\
\hline $\begin{array}{c}\text { Cardinal } \\
(\mathrm{n}=5)\end{array}$ & $5.4 \times 10^{8}$ & $4.3 \times 10^{5}$ & 0 & 0 & $5.2 \times 10^{6}$ & 0 & $1.3 \times 10^{5}$ & $7.5 \times 10^{5}$ & 0 & $8.2 \times 10^{5}$ \\
\hline $\begin{array}{l}\text { Esprit } \\
(\mathrm{n}=5)\end{array}$ & $9.8 \times 10^{8}$ & $6.3 \times 10^{5}$ & 0 & 0 & $7.7 \times 10^{6}$ & 0 & $1.3 \times 10^{7}$ & $9 \times 10^{5}$ & 0 & $7.3 \times 10^{5}$ \\
\hline $\begin{array}{c}\text { Meridian } \\
(\mathrm{n}=5) \\
\text { Lady }\end{array}$ & $8.7 \times 10^{8}$ & $7.7 \times 10^{5}$ & 0 & $6.3 \times 10^{6}$ & 0 & $2 \times 10^{5}$ & $5.4 \times 10^{6}$ & $7.3 \times 10^{5}$ & 0 & $8.5 \times 10^{5}$ \\
\hline $\begin{array}{c}\text { Rossett } \\
(\mathrm{n}=5)\end{array}$ & $4.8 \times 10^{8}$ & $5.7 \times 10^{5}$ & 0 & 0 & $2.8 \times 10^{5}$ & 0 & $1.1 \times 10^{7}$ & $4.4 \times 10^{5}$ & 0 & $7.6 \times 10^{5}$ \\
\hline $\begin{array}{l}\text { Astrix } \\
(\mathrm{n}=5)\end{array}$ & $2.3 \times 10^{9}$ & 0 & $2.0 \times 10^{4}$ & 0 & 0 & 0 & 0 & $2.0 \times 10^{6}$ & 0 & $2.4 \times 10^{6}$ \\
\hline $\begin{array}{l}\text { Soikat } \\
(\mathrm{n}=5)\end{array}$ & $1.2 \times 10^{6}$ & 0 & 0 & 0 & 0 & 0 & $1.2 \times 10^{5}$ & $1.5 \times 10^{6}$ & 0 & $6.4 \times 10^{7}$ \\
\hline $\begin{array}{l}\text { Yellow } \\
\text { flesh } \\
(\mathrm{n}=5)\end{array}$ & $7.5 \times 10^{7}$ & $5 \times 10^{4}$ & 0 & 0 & $1.3 \times 10^{6}$ & 0 & 0 & $1 \times 10^{7}$ & 0 & $1 \times 10^{5}$ \\
\hline $\begin{array}{l}\text { Red } \\
(\mathrm{n}=5)\end{array}$ & $2.5 \times 10^{8}$ & 0 & 0 & 0 & $8 \times 10^{5}$ & 0 & 0 & $2.8 \times 10^{5}$ & 0 & $2.8 \times 10^{6}$ \\
\hline $\begin{array}{l}\text { Russet } \\
(\mathrm{n}=5)\end{array}$ & $1 \times 10^{8}$ & 0 & 0 & 0 & $1.5 \times 10^{7}$ & 0 & 0 & $8 \times 10^{5}$ & 0 & $8 \times 10^{5}$ \\
\hline $\begin{array}{l}\text { White } \\
(\mathrm{n}=5)\end{array}$ & $2 \times 10^{7}$ & $4 \times 10^{5}$ & 0 & 0 & $7 \times 10^{5}$ & 0 & 0 & $1.3 \times 10^{5}$ & 0 & $1.3 \times 10^{7}$ \\
\hline $\begin{array}{l}\text { Sweet } \\
(\mathrm{n}=5)\end{array}$ & $2.5 \times 10^{7}$ & $2 \times 10^{5}$ & 0 & 0 & - & 0 & 0 & $2 \times 10^{7}$ & 0 & $2 \times 10^{7}$ \\
\hline $\begin{array}{c}\text { Purples } \\
(n=5)\end{array}$ & $3.2 \times 10^{8}$ & $1.6 \times 10^{5}$ & $2 \times 10^{5}$ & 0 & $1.2 \times 10^{5}$ & 0 & 0 & $1.7 \times 10^{7}$ & 0 & $3.7 \times 10^{7}$ \\
\hline $\begin{array}{l}\text { Petites } \\
(\mathrm{n}=5)\end{array}$ & $1.2 \times 10^{7}$ & 0 & 0 & $1.4 \times 10^{5}$ & 0 & 0 & 0 & $2.6 \times 10^{7}$ & 0 & $2.8 \times 10^{7}$ \\
\hline
\end{tabular}

TVB = Total Viable Count.

"Quantification was done "after enrichment". Before enrichment, the recovery was nil.

All the experiments were performed three times and the results were reproducible.

TABLE 2. Results of biochemical tests

\begin{tabular}{|c|c|c|c|c|c|c|c|c|c|c|c|}
\hline \multirow{2}{*}{$\begin{array}{c}\text { Assumed } \\
\text { Pathogenic microorganisms }\end{array}$} & \multicolumn{4}{|c|}{ TSI } & \multirow{2}{*}{ Motility } & \multirow{2}{*}{$\begin{array}{c}\text { Indole } \\
\text { Production }\end{array}$} & \multirow{2}{*}{ MR } & \multirow{2}{*}{ VP } & \multirow{2}{*}{$\begin{array}{c}\text { Citrate } \\
\text { utilization }\end{array}$} & \multirow{2}{*}{ Catalase } & \multirow{2}{*}{ Oxidase } \\
\hline & Slant & Butt & Gas & $\mathrm{H}_{2} \mathrm{~S}$ & & & & & & & \\
\hline Escherichia coli & $\bar{Y}$ & $\bar{Y}$ & + & - & + & + & + & - & - & + & - \\
\hline Klebsiella spp. & $\mathrm{Y}$ & $\mathrm{Y}$ & + & - & + & - & - & + & + & + & - \\
\hline Salmonella spp. & $\mathrm{R}$ & $\mathrm{Y}$ & - & + & + & - & + & - & - & + & - \\
\hline Shigella spp. & $\mathrm{R}$ & $\mathrm{Y}$ & - & - & - & + & + & - & - & + & - \\
\hline Vibrio spp. & $\mathrm{R}$ & Y & - & - & + & - & + & - & - & + & + \\
\hline Pseudomonas spp. & $\mathrm{R}$ & $\mathrm{R}$ & - & - & - & - & - & - & - & + & - \\
\hline Staphylococcus spp. & Y & $\mathrm{Y}$ & - & - & - & - & + & + & - & + & - \\
\hline Bacillus spp. & $\mathrm{R}$ & $\mathrm{Y}$ & - & - & - & - & - & + & - & + & - \\
\hline
\end{tabular}

TSI $=$ Triple Sugar Iron Test $; \mathrm{Y}=$ Yellow (Acidic), $\mathrm{R}=$ Red (Alkaline); MR = Methyl Red; VP = Voges-Proskauer

of the samples during growing, harvesting, storing and shipping. Food handlers with dirty hands or wearing soiled uniforms might also contaminate the items.

Existence of the drug-resistance isolates. In our study, most of the contaminating isolates were found to be resistant against ampicillin $(10 \mu \mathrm{g})$, amoxicillin $(30 \mu \mathrm{g})$, and erythromycin $(15 \mu \mathrm{g})$. Sensitivity was noted against ciprofloxacine $(5 \mu \mathrm{g})$, tetracycline $(30 \mu \mathrm{g})$ and chloramphenicol (30 $\mu \mathrm{g}$ ) (Table 3 ). The resistance of microorganisms against more than one antibiotics mentioned in this study might pose public health hazards. Coherent with this study, previous studies conducted in Bangladesh on different food items and water also found huge array of drug resistant pathogens $(16,22,28,31,34$, 35). The resistance trait of the pathogens may create serious clinical obstacle in diseases medication during 
TABLE 3. Antibacterial susceptibility test

\begin{tabular}{|c|c|c|c|c|c|c|c|c|}
\hline Antibiotic & $\begin{array}{l}\text { Disk } \\
\text { content }\end{array}$ & $\begin{array}{l}\text { Klebsiella } \\
\text { spp. }\end{array}$ & $\begin{array}{l}\text { Salmonella } \\
\text { spp. }\end{array}$ & $\begin{array}{l}\text { Vibrio } \\
\text { spp. }\end{array}$ & $\begin{array}{l}\text { Staphylococcus } \\
\text { spp. }\end{array}$ & E. coli & $\begin{array}{l}\text { Shigella } \\
\text { spp. }\end{array}$ & $\begin{array}{l}\text { Bacillus } \\
\text { spp. }\end{array}$ \\
\hline Polymyxin B & 300 units & $\bar{S}$ & $\mathrm{ND}$ & ND & $\mathrm{R}$ & $\bar{S}$ & ND & $\mathrm{S}$ \\
\hline Kanamycin & $30 \mu \mathrm{g}$ & ND & $\mathrm{S}$ & $\mathrm{S}$ & $\mathrm{S}$ & ND & ND & ND \\
\hline Streptomycin & $10 \mu \mathrm{g}$ & ND & ND & ND & ND & ND & ND & $\mathrm{R}$ \\
\hline Vancomycin & $30 \mu \mathrm{g}$ & ND & ND & $\mathrm{R}$ & ND & ND & $\mathrm{R}$ & S \\
\hline Gentamicin & $10 \mu \mathrm{g}$ & ND & $S$ & ND & ND & ND & $S$ & $S$ \\
\hline Nalidixic acid & $30 \mu \mathrm{g}$ & ND & S & $\mathrm{R}$ & ND & ND & S & ND \\
\hline Azythromycin & $15 \mu \mathrm{g}$ & ND & $\mathrm{S}$ & $\mathrm{R}$ & ND & ND & ND & ND \\
\hline Penicillin G & $10 \mu \mathrm{g}$ & ND & ND & ND & $\mathrm{R}$ & ND & ND & $\mathrm{R}$ \\
\hline $\begin{array}{l}\text { Trimethoprime- } \\
\text { Sulphamethoxazole }\end{array}$ & $25 \mu \mathrm{g}$ & $\mathrm{S}$ & $\mathrm{S}$ & ND & $\mathrm{R}$ & $\mathrm{S}$ & $\mathrm{S}$ & $\mathrm{S}$ \\
\hline Erythromycin & $15 \mu \mathrm{g}$ & $\mathrm{S}$ & ND & ND & $\mathrm{R}$ & $\mathrm{R}$ & ND & $S$ \\
\hline Amoxicillin & $30 \mu \mathrm{g}$ & $\mathrm{R}$ & $\mathrm{R}$ & $\mathrm{R}$ & $\mathrm{S}$ & $\mathrm{S}$ & ND & $\mathrm{S}$ \\
\hline Ceftriaxone & $30 \mu \mathrm{g}$ & $\mathrm{R}$ & ND & $S$ & S & $S$ & $S$ & ND \\
\hline Ciprofloxacin & $5 \mu \mathrm{g}$ & $\mathrm{S}$ & $\mathrm{S}$ & ND & $\mathrm{S}$ & $\mathrm{S}$ & $\mathrm{S}$ & ND \\
\hline Streptomycin & $10 \mu \mathrm{g}$ & $\mathrm{R}$ & ND & $\mathrm{S}$ & $\mathrm{S}$ & $\mathrm{R}$ & ND & $\mathrm{R}$ \\
\hline Ampicillin & $10 \mu \mathrm{g}$ & $\mathrm{R}$ & $\mathrm{R}$ & $\mathrm{R}$ & $S$ & $\mathrm{R}$ & ND & $S$ \\
\hline Tetracyclin & $30 \mu \mathrm{g}$ & $\mathrm{S}$ & ND & $\mathrm{R}$ & S & S & ND & ND \\
\hline Chloramphenicol & $30 \mu \mathrm{g}$ & $\mathrm{S}$ & $\mathrm{S}$ & $\mathrm{R}$ & $\mathrm{S}$ & $\mathrm{S}$ & $\mathrm{S}$ & $\mathrm{R}$ \\
\hline Cefixime & $5 \mu \mathrm{g}$ & $\mathrm{R}$ & ND & ND & $\mathrm{S}$ & $\mathrm{S}$ & ND & $S$ \\
\hline
\end{tabular}

$\mathrm{R}=$ Resistant $\mathrm{S}=$ Susceptible $; \mathrm{ND}=$ Not done

food borne disease outbreaks.

Antibacterial profile of potato samples. Presence of any natural antimicrobial activity in such food items would be interesting as it could further induce the production of more effective drugs (39). Several studies assessed the natural antimicrobial activity of the vegetable samples globally $(33,34,39,40)$. The natural bacteria killing activity of the vegetables and/or other food samples could be a potential replacement of the chemical medicines, which can reduce the high possibility rate of the side effects of chemical medicine and can easily accelerate the shelf life of the vegetable. Based on those previous investigation, the present study determined the anti-microbial activity of the potato samples as a new research findings in Bangladesh (Table 4). Interestingly in present study, antibacterial activity was found in the Astrix samples $(9 \mathrm{~mm})$ against Shigella spp. and Russet samples $(11 \mathrm{~mm})$ against Staphylococcus spp. However, the other samples showed no antimicrobial activity against any of the bacterial isolates. Therefore, the findings suggest that further study could be conducted focusing the selfprotecting mechanism of the potato samples.

\section{CONCLUSION}

Like other developed countries, people of Bangladesh are also leaning towards healthy and hygienic diets as the life style is changing. As suggested from other studies together with the current one, intake of vegetables contaminated with microorganisms may impart foodborne complications. Present study generated important data regarding food hygiene and service to different sectors of national economy such as agriculture, health, food and environmental sciences. Finally, the present work would further furnish important information about the sanitary condition of other vegetables that we consume and also on how we can minimize the risk of getting different diseases.

\section{ACKNOWLEDGEMENTS}

The work was financed and facilitated by Stamford University Bangladesh.

\section{REFERENCES}

1. Ross, H. 1986. Potato breeding problems and perspectives. Food and Agricultural Organization, Hamburg, Germany.

2. Douches, D. S., et al. 2004. Field and storage testing Bt-potatoes for resistance to potato tuber moth (Lepidoptera: Gelichiidae). J. Econ. Entomol. 97: 14251431.

3. Rytel, E., et al. 2011. Anti-nutritional compounds in potatoes, depending on the type of raw material and conditions of processing potatoes into food products. Potato. V. Food. 5: 15-22.

4. Hoque, M. E. 2000. Crop diversification in Bangladesh. In M. K. Papdemetriou, and F. T. Dent (eds.); Crop diversification in the Asia-Pacific region. Food and Agriculture Organization, Bangkok, Thailand.

5. Visser, G. F. R., et al. 2009. Sequencing the potato genome: Outline and first results to come from the elucidation of the sequence of the world's third most important food crop. Am. J. Potato. Res. 86: 417-429.

6. Zepp, G., F. Kuchler, and G, Lucier. 1998. Food safety and fresh fruits and vegetables: is there a difference between imported and domestically produced products. Vegetables and Specialties, Situation and Outlook Report 274: 2328 .

7. Southon, S. 2000. Increased fruit and vegetable consumption within the EU: potential health benefits. Food Res. Int. 33: 211-217.

8. Wargovich, M. J. 2000. Anticancer properties of fruits and vegetables. Hort. Sci. 35: 573-575.

9. Hrabovska, D., J. Heldak, and B. Volnova. 2013. Changes in the content of vitamin $\mathrm{C}$ in potato tubers depending on variety. J. Microbiol. Biotechnol. Food Sci. 2: 2052-2058.

10. Beuchat, L. R. 1996. Pathogenic microorganisms associated with fresh produce. J. Food Prot. 59: 204-216. 
11. Burnett, S. L., and L. R. Beuchat. 2001. Human pathogens associated with raw produce and unpasteurized juices, and difficulties in contamination. J. Ind. Microbiol. Biotechnol. 27: 104-110.

12. Solomon, E. B., S. Yaron, and K. R. Matthews. 2002. Transmission of Escherichia coli O157:H7 from contaminated manure and irrigation water to lettuce plant tissue and its subsequent internalization. Appl. Environ. Microbiol. 68: 397-400.

13. Wachtel, M. R., L. C. Whitehand, and R. E. Mandrell. 2002 Association of Escherichia coli $0157: \mathrm{H} 7$ with pre-harvest leaf lettuce upon exposure to contaminated irrigation water. J. Food Protection 65: 1825.

14. Guo, X., et al. 2002. Evidence of association of salmonellae with tomato plants grown hydroponically in inoculated nutrient solution. Appl. Environ. Microbiol. 68: 3639-3643.

15. Nipa, M. N., et al. 2011. Prevalence of multi drug resistant bacteria on raw salad vegetables sold in major markets of Chittagong city, Bangladesh. Middle East. J. Scientific Res. 10: 70-11.

16. Rahman, F., and R. Noor. 2012. Prevalence of pathogenic bacteria in common salad vegetables of Dhaka metropolis. Bangladesh J. Botany 41: $150-162$.

17. Tauxe, R. V. 1997. Emerging foodborne disease: an evolving public health challenge. Emerging Infect. Dis. 4: 425-434.

18. Tenover, F. C. 2006. Mechanisms of antimicrobial resistance in bacteria Am. J. Med. 119: 3-10

19. Mathew, A. G., R. Cissell, and S. Liamthong. 2007. Antibiotic resistance in bacteria associated with food animals: a United States perspective of livestock production. Foodborne Pathog, Dis. 4: 115-133.

20. Allerberger, F., H, and Mittermayer. 2008. Antimicrobial stewardship. Clin. Microbiol. Infection. 14: 197-199.

21. Dutta, S., et al. 2013. Study of antimicrobial susceptibility of clinically significant microorganisms isolated from selected areas of Dhaka, Bangladesh. Bangladesh J. Med. Sci. 12: $34-42$.

22. Noor, R., et al. 2013. Microbiological study of major sea fish available in local markets of Dhaka city, Bangladesh. J. Microbiol. Biotechnol. Food Sci. 2: 2420-2430.

23. American Public Health Association. 1998 Standard Methods for the Examination of Water and Wastewater. American Public Health Association: Washington DC.

24. Cappuccino, J. G., and N. Sherman. 1996. Microbiology - A Laboratory Manual. Menlo Park. The Benjamin/Cummings Publishing Co., Inc, California.
25. Colwell, R. R, 2000. Non-culturable microorganisms in the environment American Society of Microbiology, Washington DC, USA

26. Oliver, J. D. 2005. The viable but non-culturable state in bacteria. J. Microbiol. 43: 93-100.

27. Alfrad, E. B. 2007. Bensons microbiological applications. Mcgraw-Hill Book Company, New York.

28. Acharjee, M., F. Rahman, F. Jahan, and R. Noor, 2013. Bacterial proliferation in municipal water supplied in mirpur locality of Dhaka city, Bangladesh. CLEAN- Soil, Air, Water 41: 1-8

29. Bauer, A. W., W. M. M. Kirby, J. C. Sherris, and M. Tierch. 1966 Antibiotic susceptibility testing by a standardized single disc method. Am. J. Clin. Pathol. 45: 493-496.

30. Ferraro, M. J., W. A. Craig, and M. N. Dudley. 2001 Performance standards for antimicrobial susceptibility testing. NCCLS informational supplement, Pennsylvania, USA.

31. Munshi, S. K., M. M. Rahman, and R. Noor. 2012. Detection of virulence potential of diarrheagenic Escherichia coli isolated from surface water of rivers surrounding Dhaka city. J. Bangladesh Acad. Sci. 36: 109-121.

32. Jagessar, R. C., A. Mars, and G. Gones. 2008. Selective antimicrobial properties of leaf extract against various micro-organisms using disc diffusion and agar well diffusion method. J. Nat. Sci. 6: 24-38.

33. Hussain, A., S. Wahab, I. Zarin, and M. D. S. Hussain. 2010. Antibacterial activity of the leaves of Coccinia indica (W. and A) of India. Adv. Biol. Res. 4: $241-248$

34. Ahmed, T., et al. 2013. Identification of drug-resistant bacteria among export quality shrimp samples in Bangladesh. Asian J. Microbiol. Biotech. Env. Sc. 15 (4): 655-660.

35. Noor, R., et al. 2013 Microbiological study of vendor and packed fruit juices locally available in Dhaka city, Bangladesh. Int. Food Res. J. 20: 1011-1015.

36. Mahbub, K. R., A. Nahar, M. M. Ahmed, and A. Chakraborty. 2011. A quality analysis of Dhaka WASA drinking water: detection and biochemica characterization of the isolates. J. Environ. Sci. Nat. Res. 4: 41-49.

37. Butt, A. A., K. E. Aldridge, and C. V. Sanders. 2004. Infections related to the ingestion of seafood part 1: viral and bacterial infections. Lancet Infect. Dis. 4: 201-212.

38. Alice, N. P. 1997. Manure and microbes: public and animal health problem. J. Dairy Sci. 80: 2673-2681.

39. Dubey, A., N. Mishra, and N. Singh. 2010. Antimicrobial activity of some selected vegetables. Int. J. Appl. Biol. Pharm. Technol. 1: 994-999.

40. Kyung, K. H., and H. P. Fleming. 1994. Antibacterial activity of cabbage juice against lactic acid bacteria. J. Food. Sci. 59: 125-129. 